\title{
Prevalence of Asymptomatic Bacteriuria in Antenatal Women Coming to NRIMC\&GH
}

\author{
K. RAMALINGAM ${ }^{1}$, VIJAYA MADHURI SURASANI ${ }^{2}$, MOUNICA. BOLLU ${ }^{3}$
}

\begin{abstract}
Objective(s): The aim of the study was to determine the prevalence of asymptomatic bacteriuria in pregnant women attending the antenatal OPD and to treat them. Also to identify the organisms causing asymptomatic bacteriuria and the risk factors in pregnant women.

Materials and Methods: The present observational study was conducted in the Department of Obstetrics, NRI Medical College, Chinakakani, Mangalagiri from Aug-2012 to Aug-2014. Material for the study consisted of 100 urine samples obtained from asymptomatic 100 pregnant women in their first antenatal visit. The study group consisted of cases from in and around Mangalagiri, attending antenatal OPD, NRI Medical College, Chinakakani.

Each patient was first asked whether she had any symptom of urinary tract infection such as dysuria, urgency, haematuria, loin pain and fever. After ascertaining that she was asymptomatic, preliminary data on maternal age, gravidity, parity and period of gestation were collected on a predesigned proforma. Detailed history about previous antenatal check-up, hypertension were also taken. A clean-catch midstream urine sample was collected and MacConkey agar, Blood agar plates were used for culture.Bacterial counts were done to determine the number of microorganisms per millilitre.Antimicrobial susceptibility testing was done for the isolates by the Kirby-Bauer method (disc diffusion).

Results: The prevalence of asymptomatic bacteriuria in the study group was 15\%. Escherichia coli, Klebsiella pneumoniae, Pseudomonas aeruginosa, Staphylococcus saprophyticus, Staphylococcus aureus were the isolates in the study group. Isolates showed maximum susceptibility to gentamycin followed by cefotaxime, nitrofurantoin and cotrimoxazole. They showed high degree of resistance to cephalexin and ceftriaxone. All the asymptomatic pregnant women with significant bacteriuria were treated and asked to come back after 7-10 days for repeat culture and susceptibility testing, which was done as a part of follow-up.
\end{abstract}

Conclusion: Increasing gestational period showed increase in the incidence of asymptomatic bacteriuria and also increased incidence was seen in the pregnants with anaemia. Routine antenatal screening for asymptomatic bacteriuria should be implemented and treatment of those showing bacteriuria must be practiced to prevent adverse perinatal outcome. Untreated asymptomatic bacteriuria progresses to pyelonephritis (13-27\%). Therefore, routine screening for bacteriuria is recommended during pregnancy.

\section{Introduction:}

Infectious diseases have been the bane of mankind for centuries and continue to cause high morbidity and sufferings worldwide. Humans and animals have abundant bacterial flora that are usually harmless. A general balance exists between man (host) and his environment. The host-parasite interaction is influenced by host factors as well as the infecting microorganism. The outcome of this interaction can range from no demonstrable effect to death. All infections do not invariably result in disease. Some infections remain asymptomatic and others may lead

1. Professor of Obstetrics and Gynaecology, N.R.I Medical College and General Hospital, Chinakakani, Guntur

2. Consultant (Obstetrics and Gynaecology), Guntur

3. Department of Pharmacy Practice, Government General Hospital, Guntur 
to development of signs and symptoms (disease) after breakdown of host-parasite relationship in favour of the parasite.

Urinary tract is second only to the respiratory tract in acquiring microbial infection, especially in females. Thirty to forty percent of specimens received in most clinical labs are urine samples of patients with suspected infection of urinary tract. ${ }^{1}$ Urinary tract infection may be asymptomatic or symptomatic.

Asymptomatic bacteriuria is defined as a significant bacterial count ( $\geq 10^{5}$ organims $/ \mathrm{mL}$ ) present in the urine of a person without symptoms.Asymptomatic bacteriuria is the most common bacterial infection requiring medical treatment in pregnancy. The asymptomatic urinary tract infection is a persistent, actively multiplying bacteria within the urinary tract without any symptoms of infection ${ }^{2}$. The prevalence in pregnancy varies from 2 to $7 \%$ and it depends on parity, race, and socioeconomic status. ${ }^{3}$ If asymptomatic bacteriuria is not treated, approximately $25 \%$ of women will subsequently develop acute symptoms of an infection during pregnancy. ${ }^{3}$ Asymptomatic bacteriuria (ASB) is an entity with possibly serious consequences in the form of fetal and maternal morbidity. ${ }^{4}$ It can cause maternal anemia, acute pyelonephritis, recurrent infection, preterm labour, ${ }^{5}$ septicemia and even death of the mother. ${ }^{6}$ It can cause intra uterine growth restriction ${ }^{7}$ prematurity and low birth weight of the fetus ${ }^{8}$ and fetal mortality ${ }^{9}$. There is an increased chance of urinary tract infection in females as compared to males due to short urethra $(4 \mathrm{~cm})$, proximity to the anus contaminated heavily with microorganisms. ${ }^{10}$

Urinary tract infections are more common in pregnants than non-pregnants because urinary tract undergoes profound physiologic and anatomic changes during pregnancy that facilitates the development of symptomatic urinary tract infections in the women with bacteriuria. ${ }^{11}$

The gold standard for screening of asymptomatic bacteriuria is growing bacterial cultures of urine samples from pregnant women.Oral antibiotics are the treatment of choice of asymptomatic bacteriuria. Antibiotic therapy should be based on urine culture and susceptibility testing. Drugs that cause teratogenesis, foetal side effects (hemolytic anemia, jaundice) should be avoided (or) used with caution when therapeutic benefits out weigh the risk. In pregnancy, $13-27 \%$ of untreated patients with asymptomatic bacteriuria develop pyelonephritis, usually in the third trimester (or) in the puerperium. ${ }^{19}$ Pyelonephritis, if it develops leads to increased foetal loss due to

abortions, intrauterine foetal deaths and prematurity.

Screening for asymptomatic bacteriuria is important during pregnancy, where there is strong evidence that treatment is efficacious in improving outcome. Universal screening for asymptomatic bacteriuria in pregnancy is recommended in the United Kingdom $(\text { NICE 2008) })^{12}$, the United States (Nicolle et al 2005) ${ }^{13}$, Canada (Nicolle 1994) ${ }^{14}$ based on the effectiveness of available treatments and the reduced risk of pyelonephritis. Given the benefits of detecting asymptomatic bacteriuria in pregnancy, prenatal testing should be carried out

by urine culture to reduce the risk of false negatives.

Studies by Rouse et al. (1995) ${ }^{15}$ have shown that compared with a policy of no screening, screening for and treatment of asymptomatic bacteriuria to prevent pyelonephritis in pregnancy is cost-beneficial.

Based on these study results our aim of this study was to screen the pregnant women for asymptomatic bacteriuria.

\section{Material and Methods:}

The present study was conducted in the Department of Obstetrics, NRI Medical College, Chinakakani, Mangalagiri from Aug-2012 to Aug-2014. Material for the study consisted of 100 urine samples obtained from asymptomatic pregnant women in their first antenatal visit. The study group consisted of cases from in and around Mangalagiri, attending antenatal OPD, NRI Medical College, Chinakakani.

Each patient was first asked whether she had any symptom of urinary tract infection such as dysuria, urgency, haematuria, loin pain and fever. After ascertaining that she was asymptomatic, preliminary data on maternal age, gravidity, parity and period of gestation were collected on a predesigned proforma. Detailed history about previous antenatal check-up, hypertension were also taken.

The results of baseline investigations such as haemoglobin levels, urine albumin and sugar and HIV status were collected. Haemoglobin level below $10 \mathrm{gm} \%$ is considered as anaemic and those above it as non-anaemic. Social class was classified according 
to educational level, monthly income and living standard as low, middle and higher social class.

According to standard guidelines, a clean-catch midstream urine sample was collected in a sterile wide mouthed container, which was labelled with patient's name and out patient (OP) number and they were advised to comeback after 3 days for follow up.

All the samples were immediately sent to and processed without any delay at the Department of Microbiology, at NRI Medical College, Chinakakani.

Each of the specimens was subjected to culture by the standard loop technique (delivering a volume of $0.01 \mathrm{ml}$ of urine). This was used to inoculate a set of MacConkey agar and Blood agar plates for semiquantitative cultures. The plates were incubated at $37^{\circ} \mathrm{C}$ overnight. Bacterial counts were done by counting the number of colonies manually and multiplying the number of colony forming units (CFUs) by 1000 , to determine the number of microorganisms per milliliter in the original specimen. Counts above $10^{5}$ organisms $/ \mathrm{ml}$. were considered as significant bacteriuria. Bacterial counts less than this were considered insignificant and growth of more than two types of organisms was considered as contamination.

Antimicrobial susceptibility testing was done for the isolates by the Kirby-Bauer method (disc diffusion). 3 to 4 similar colonies were selected and transferred into $5 \mathrm{ml}$ of Mueller-Hinton broth and incubated for 4 hours. Then the turbidity was compared to 0.5 McFarland standard.

Sterile swab on a wooden applicator was dipped into this inoculum and the soaked swab was rotated firmly against the upper inside wall of the tube to express excess fluid. Then the entire agar (Mueller-Hinton agar) surface was streaked with the swab three times, turning the plate at $60^{\circ}$ angle between each streaking. Allowed the inoculum to dry for $5-15$ minutes with lid in place. Antibiotic discs were placed (6 discs per plate). Then the plates were incubated at $37^{\circ} \mathrm{C}$ overnight. With the help of a scale, the zone of inhibitions were measured and recorded.

The following drugs were used:

\begin{tabular}{lll}
\hline 1. & Gentamycin & $10 \mu \mathrm{gm}$ \\
2. & Nitrofurantoin & $300 \mu \mathrm{gm}$ \\
3. & Ceftriaxone & $30 \mu \mathrm{gm}$ \\
4. Cefotaxime & $30 \mu \mathrm{gm}$ \\
5. & Cephalexin & $30 \mu \mathrm{gm}$ \\
6. & Cotrimoxazole & $25 \mu \mathrm{gm}$ (sulphamethoxazole- \\
& & $23.75 \mu \mathrm{gm}+$ trimethoprim- \\
& & $1.25 \mu \mathrm{gm})$ \\
\hline
\end{tabular}

Culture positive reports were seen and all the asymptomatic pregnant women with significant bacteriuria were treated and asked to come back after 7-10 days for repeat culture and susceptibility testing, which was done as a part of follow-up.

\section{Results:}

The present study included 100 asymptomatic bacteriuria pregnant women in the study group attending the antenatal OPD, NRI Medical College Chinakakani. Among them $15 \%$ cases found culture positive.

\section{Table-I}

Distribution of cases according to age

\begin{tabular}{|c|c|c|c|c|}
\hline \multirow[t]{2}{*}{$\begin{array}{l}\text { Age in } \\
\text { years }\end{array}$} & \multicolumn{2}{|c|}{$\begin{array}{l}\text { No. of Cases } \\
(100)\end{array}$} & \multicolumn{2}{|c|}{$\begin{array}{c}\text { Culture positive } \\
\text { cases (15) }\end{array}$} \\
\hline & $\mathrm{N}$ & $\%$ & $\mathrm{~N}$ & $\%$ \\
\hline $18-20$ & 32 & 32 & 5 & 33.33 \\
\hline $21-23$ & 41 & 41 & 7 & 46.67 \\
\hline $24-26$ & 18 & 18 & 10 & 6.67 \\
\hline $27-29$ & 9 & 9 & 2 & 13.33 \\
\hline
\end{tabular}

Table 1 shows the age range of the patient was 18-29 years, of which $41 \%$ was within $21-23$ years of age and culture positive cases was also more (46.67\%) among this group.

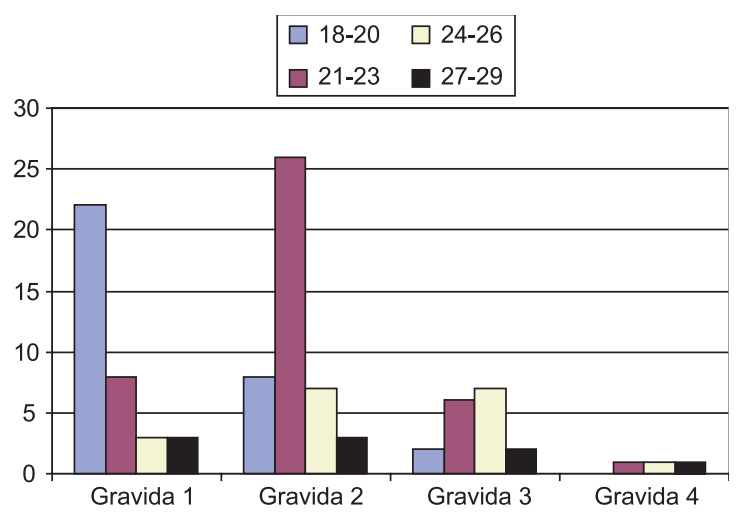

Fig.-1: Distribution of cases according to age \& gravida

Table-II

Distribution of cases according to gravida

\begin{tabular}{llllcc}
\hline Gravida & \multicolumn{2}{c}{$\begin{array}{c}\text { No. of Cases } \\
(100)\end{array}$} & & \multicolumn{2}{c}{$\begin{array}{c}\text { Culture positive } \\
\text { cases (15) }\end{array}$} \\
\cline { 2 - 3 } \cline { 5 - 6 } & $N$ & $\%$ & & $N$ & $\%$ \\
\hline $1^{\text {st }}$ & 36 & 36 & & 4 & 26.67 \\
$2^{\text {nd }}$ & 44 & 44 & & 9 & 60.00 \\
$3^{\text {rd }}$ & 17 & 17 & & 2 & 13.33 \\
$4^{\text {th }}$ & 3 & 3 & & 0 & 00 \\
\hline
\end{tabular}


Most of the patients are gravida $2^{\text {nd }}(44 \%)$ and culture positive cases are also high (60\%) among $2^{\text {nd }}$ gravida (Table 2 and Fig 1).

Table-III

Distribution of cases according to trimester of pregnancy

\begin{tabular}{|c|c|c|c|c|}
\hline \multirow[t]{2}{*}{$\begin{array}{l}\text { Period of } \\
\text { gestation }\end{array}$} & \multicolumn{2}{|c|}{$\begin{array}{l}\text { No. of Cases } \\
\quad(100)\end{array}$} & \multicolumn{2}{|c|}{$\begin{array}{l}\text { Culture positive } \\
\text { cases (15) }\end{array}$} \\
\hline & $\bar{N}$ & $\overline{\%}$ & $\mathrm{~N}$ & $\%$ \\
\hline $1^{\text {st }}$ trimester & 31 & 31 & 3 & 20.00 \\
\hline $2^{\text {nd }}$ trimester & 25 & 25 & 4 & 26.67 \\
\hline $3^{\text {rd }}$ trimester & 44 & 25 & 8 & 53.33 \\
\hline
\end{tabular}

The no. of cases in the first trimester were $31 \%$, in second trimester $25 \%$ and in third trimester $44 \%$. Three (3) cases, 4 cases and 8 cases were culture positive in $1^{\text {st }}, 2^{\text {nd }}$ and $3^{\text {rd }}$ trimester respectively. Most of the cases of asymptomatic bacteriuria were found during $3^{\text {rd }}$ trimester (53.33\%) of pregnancy (Table 3 ).

Table-IV

Distribution of cases according to risk factor

\begin{tabular}{|c|c|c|c|c|}
\hline \multirow[t]{2}{*}{ Risk Factor } & \multicolumn{2}{|c|}{$\begin{array}{l}\text { No. of Cases } \\
(100)\end{array}$} & \multicolumn{2}{|c|}{$\begin{array}{c}\text { Culture positive } \\
\text { cases (15) }\end{array}$} \\
\hline & $\mathrm{N}$ & $\%$ & $\mathrm{~N}$ & $\%$ \\
\hline Anaemic & 52 & 52 & 11 & 21.15 \\
\hline Non-Anaemic & 48 & 48 & 4 & 8.33 \\
\hline
\end{tabular}

Taking a threshold value of haemoglobin as $10 \mathrm{gm} \%$ $52 \%$ patients were anaemic and $48 \%$ were nonanaemic. Higher number, 11 out of 52 (21.15\%) of culture positive cases were found within anaemic group. On the other hand only 4 out of $48(8.33 \%)$ were culture positive among non-anaemic group. This is reflecting a strong association between bacteriuria and anaemia. Poor nutrition and susceptibility to infection might have some role (Table 4).
Table-V

Distribution of cases according to social class

\begin{tabular}{llllll}
\hline Social Class & \multicolumn{2}{c}{$\begin{array}{c}\text { No. of Cases } \\
(100)\end{array}$} & & \multicolumn{2}{c}{$\begin{array}{c}\text { Culture positive } \\
\text { cases (15) }\end{array}$} \\
\cline { 2 - 3 } \cline { 6 - 7 } & $\mathrm{N}$ & & & $\mathrm{N}$ & $\%$ \\
\hline Higher Class & 24 & 24 & & 2 & 13.33 \\
Middle Class & 30 & 30 & & 4 & 26.67 \\
Lower Class & 46 & 46 & & 9 & 60.00 \\
\hline
\end{tabular}

Table 5 shows that prevalence is more in lower social class patients. Out of 15 positive cases 9 (60\%) from lower social class.

Among the 15 (15\%) culture positive cases in this study isolates were Escherichia coli 5 (33.33\%) followed by Klebsiella pneumoniae 3 (20.00\%), Staphylococcus aureus 3 (20.00\%), Staphylococcus saprophyticus 2 (13.33\%) and Pseudomonas aeruginosa 2 (13.33\%).

Escherichia coli were highly susceptible to Gentamicin (100\%) followed by Cefotaxime (80\%), Cotrimoxazole (80\%), Nitrofurantoin (60\%), Cephalexin (40\%), Ceftriaxone (20\%), in the decreasing order.

Klebsiella pneumoniae were highly susceptible to Gentamicin (100\%) followed by Cefotaxime(66.6\%), Nitrofurantoin (66.6\%), Cotrimoxazole (66.6\%), Cephalexin (33.3\%), Ceftriaxone (33.3\%), in the decreasing order.

Pseudomonas aeruginosa were highly susceptible to cefotaxime (100\%), Gentamicin (100\%), Nitrofurantoin $(50 \%)$, Cotrimoxazole (50\%), Ceftriaxone (50\%), Cephalexin (0\%), in the decreasing order.

Staph. saprophyticus were highly susceptible to Gentamicin (100\%), followed by Cefotaxime (100\%), Cotrimoxazole (50\%), Nitrofurantoin (50\%), Cephalexin $(50 \%)$, Ceftriaxone (0\%), in the decreasing order.

Table-VI

Isolates and their antibiotic susceptible

\begin{tabular}{|c|c|c|c|c|c|c|c|}
\hline \multirow[b]{2}{*}{ ISOLATES } & \multicolumn{7}{|c|}{ Antibiotic Susceptibility (\%) } \\
\hline & $\begin{array}{c}\text { No. of Cases } \\
(N=15)\end{array}$ & Gentamicin & Cefotaxime & Cotrimoxazole & Nitrofurantoin & Cephalexin & Ceftriaxone \\
\hline \multicolumn{8}{|l|}{ Gram negative organisms } \\
\hline Escherichia coli & $5(33.33 \%)$ & $100 \%$ & $80 \%$ & $80 \%$ & $60 \%$ & $40 \%$ & $20 \%$ \\
\hline Klebsiella Pneumoniae & $3(20.00 \%)$ & $100 \%$ & $66.6 \%$ & $66.6 \%$ & $66.6 \%$ & $33.3 \%$ & $33.3 \%$ \\
\hline Pseudomonas Aeruginosa & $2(13.33 \%)$ & $100 \%$ & $100 \%$ & $50 \%$ & $50 \%$ & $0 \%$ & $50 \%$ \\
\hline \multicolumn{8}{|l|}{ Gram positive organisms } \\
\hline Staph. saprophyticus & $2(13.33 \%)$ & $100 \%$ & $100 \%$ & $50 \%$ & $50 \%$ & $50 \%$ & $0 \%$ \\
\hline Staph. aureus & $3(20.00 \%)$ & $100 \%$ & $66.6 \%$ & $66.6 \%$ & $66.6 \%$ & $33.3 \%$ & $0 \%$ \\
\hline
\end{tabular}


Staph. aureus were highly susceptible to Gentamicin $(100 \%)$, followed by cefotaxime $(66.6 \%)$, Cotrimoxazole (66.6\%), Nitrofurantoin (66.6\%), Cephalexin (33.3\%), Ceftriaxone $(0 \%)$, in the decreasing order.

\section{Discussion:}

In the present study out of 100 asymptomatic bacteriuria pregnant women, 15 showed significant bacteriuria. The incidence of asymptomatic bacteriuria in the present study is $15 \%$. Escherichia coli, Klebsiella pneumoniae, Pseudomonas aeruginosa, Staphylococcus saprophyticus, Staphylococcus aureus were the isolates in this study. Isolates showed maximum susceptibility to Gentamicin followed by cefotaxime, nitrofurantoin and cotrimoxazole. They showed high degree of resistance to cephalexin and ceftriaxone.

The review of literature revealed an incidence from $4 \%$ to $46.3 \%$ in studies conducted by various authors ${ }^{16-}$ 29 . The incidence found in this study is $15 \%$, which is within the range of those studies.

Gayathree et $\mathrm{al}^{30}$ studied 900 pregnant women who attended the Hassan District hospital, Hassan, to study the prevalence of asymptomatic bacteriuria. They found that asymptomatic bacteriuria was prevalent in $6.2 \%$ in 900 pregnant women. There was a higher prevalence of asymptomatic bacteriuria in $3^{\text {rd }}$ trimester (61.77\%) than in $2^{\text {nd }}$ trimester $(32.35 \%)$ and $1^{\text {st }}$ trimester $(5.88 \%)$ and concluded that screening for asymptomatic bacteriuria in all the three trimesters is necessary to prevent the dangerous complications, which are associated with asymptomatic bacteriuria in pregnancy. Other two studies also recommended the same ${ }^{29,31}$.

In our study prevalence of asymptomatic bacteriuria is almost the same with $18.18 \%$ in $3^{\text {rd }}$ trimester, $16 \%$ in $2^{\text {nd }}$ trimester and $9.67 \%$ in $1^{\text {st }}$ trimester (Table 3 ).

Wesley et al ${ }^{32}$ in 2002 found that the prevalence is higher among lower socio economic classes. Kiningham et al reported that low socio-economic status, sickle cell trait, diabetes mellitus and grand multi parity predispose to urinary tract infection, and each is associated with two-fold increase in the rate of bacteriuria. Lower socioeconomic status was also considered a risk factor showing that $90 \%$ of women belonged to lower socioeconomic status as compared to $10 \%$ of infected women belonging to middle class 32. The same results were observed in a study conducted at Satellite Town and Beharia colony, Bahawalpur ${ }^{33}$. This difference could be due to poor hygienic practices in lower socio- economic group. As education helps to change the attitude towards health and hygiene, so it can play an important role to decrease the prevalence of asymptomatic bacteriuria. This fact was observed in our study also. Prevalence is higher in lower socioeconomic group.

The incidence of bacteriuria was found to be more with the increasing age of pregnant women. The incidence increased from $15.62 \%$ in $18-20$ years to $22.22 \%$ in the $27-29$ years of age. The above correlation with age is also seen in some of the previous studies ${ }^{18,24}$.

Maranchie et al proved that prevalence increases with higher parity and advancing age ${ }^{34}$. Nicolle et al ${ }^{3}$ found that higher prevalence of ASB in patients with advancing maternal age is due to increasing incidence of co morbid conditions, which is associated with neurogenic bladder and increased residual urine volume or urinary reflux.All of the above studies reflected that incidence of asymptomatic bacteriuria increases with the increasing gestational period also.

In the present study, anaemia was recorded as an important risk factor for asymptomatic bacteriuria. Eleven (21.15\%) of anaemic and only 4 (8.33\%) of non-aneamic showed asymptomatic bacteriuria in this study (Table-4). Lavanya and Joagalakshmi ${ }^{22}$ found that bacteriuria in pregnancy was associated with maternal anaemia. But Fatima and Ishrat ${ }^{31}$ did not find any association between bacteriuria and anaemia.This strong association of anaemia in pregnant women with asymptomatic bacteriuria needs further evaluation.

Bacterial isolates of this study shows similar findings across different other studies 18,19,21-25,31 like Escherichia coli, Staph. Saprophyticus, Klebsiella pneumoniae, Pseudomonas aeruginosa, and Staph. aureus. Sevki et al ${ }^{35}$ shows E-coli is the predominant (76.6\%) followed by Klebsiella pneumoni (14.6\%). The results of the present study are similar to most of the other studies. In our study E coli is the predominant organism (33.33\%) followed by Klebsiella pneumoniae (20\%) (Table 6). Same organism was reported as leading cause of asymptomatic bacteriuria in pregnant women by some other authors. Fatima $\mathrm{N}$ et al ${ }^{36} \mathrm{did} \mathrm{a}$ study in which 28 women had bacteriuria giving prevalence of $4.8 \%$. Culture and sensitivity tests 
showed E-Coli to be the causative organism in $78.6 \%$ while $21.4 \%$ cases were due to other organisms.

In the present study the isolates were highly susceptible to gentamicin, cefotaxime followed by nitrofurantoin, cotrimoxazole. Marked degree of resistance was seen for cephalexin and ceftriaxone (Table-5). The susceptibility patterns of antibiotics in the present study slightly varies with that of other studies, where Gebre-Selasse reported 91\% of Escherichia coli isolates were susceptible to nitrofurantoin and $91 \%$ of them were resistant to ampicillin and amoxycillin ${ }^{22}$. Lavanya \& Jogalakshmi 23 identified maximum susceptibility to cephalexin (35.7\%) followed by nitrofurantoin (28.5\%).

Based on susceptibility patterns, drug regimens were suggested for 7-10 days to prevent the risk of early re-infection with vaginal and faecal reservoirs. The higher incidence of asymptomatic bacteriuria in the study group can be attributed to various risk factors identified in this study, such as increasing maternal age, gravidity, gestational period and anaemia.

Though a few studies have revealed asymptomatic bacteriuria as a significant contributing factor to the outcome of maternal and child health, the routine obstetrical checkup is still devoid of urine culture and susceptibility testing. Unless this is made mandatory, a positive outcome in pregnancy cannot be satisfactory. In our study only one patient had reinfection and the same patient went into preterm labour.

We found 15\% patient had bacteriuira without any symptoms. As untreated asymptomatic bacteriuria may progresses to pyelonephritis, in the light of this study finding it can be concluded that all pregnant women should be screened for asymptomatic bacteriuria to prevent serious morbidity of mother. As the procedure is simple and cheap it can be done as a routine.

\section{References:}

1. Lavanya.S.V, Jogalakshmi.D. Asymptomatic bacteriuria in antenatal women. Indian Journal of Medical Microbiology2002; 20(2): 105- 106.

2. Uncu Y, Uncu G, Esmer A et al. Should asymptomatic bacteriuria bescreened in pregnancy? Clin Exp Obstet Gynecol 2002;29:281-5.
3. Nicolle LE. Asymptomatic bacteriuria: when to screen and when to treat. Infect Dis Clin North Am 2003;17:367-394.

4. Rubenstein JN, Schaeffer AJ. Managing complicated urinary tract infections:The urologic view. Infect Dis Clin North Am 2003; 17:333-351.

5. Patterson TF, Andriole VT. Detection, significance and therapy of bacteriuria in pregnancy. Infect DisClin North Am. 1997; 1:593608.

6. Kremery S, Hromec J, Demesova D. Treatment of lower urinary tract infection in pregnancy. Int J Antimicrobe Agents. 2001; 17(4):279-82.

7. Tayo AO, Akinola OI, Ottun TA, Onakoya JAA, Ogunsanya AO.An appraisal of asymtomatic bacteriuria in pregnancy- The Lagos State University Teaching Hospital Experience.Niger J Clin Med. 2010;3(2):1-8.

8. Sharma JB., Sharma S, Gulati N et al. Prevalence of significant bacteriuria in preterm labor. J Obstet Gynecol India 1990;40:336-8.

9. Meis PJ, Michielutte R, Peters TJ et al. Factors associated with preterm birth in Cardiff, Wales Am J Obstet Gynecol. 1995;173:597-602.

10. Infections of the Urinary tract-Bailey and Scott's Diagnostic Microbiology, 13the d, 2013.

11. Patterson TF, Andriole VT. Bacteriuria in pregnancy. Infect Dis.Clin.North Am.1987: 1(4):807-22.

12. NICE (2008) Antenatal Care. Routine Care for the Healthy Pregnant Woman.National Collaborating Centre for Women's and Children's Health.Commissioned by the National Institute for Health and Clinical Excellence.London: RCOG Press.

13. Nicolle LE, Bradley S, Colgan R et al. Infectious diseases society ofAmerica guidelines for the diagnosis and treatment of asymptomatic bacteriuriain adults. Clin Infect Dis. 2005; 40: 643-54.

14. Nicolle LE. Screening for asymptomatic bacteriuria in pregnancy. In:Canadian Guide to Clinical Preventive Health Care. Ottawa: Health Canada, 1994;pp 100-106.

15. Rouse DJ, Andrews W.W, Golden BRL, OwenJ.Screening and treatment of 
asymptomatic bacteriuria of pregnancy to preventpyelonephritis : a cost effectiveness and cost befefit analysis - Obstet and Gynaecol, 1995; 86 (1): 119 - 123.

16. Kass EH. Asymptomatic infections of the urinary tract. Trans Assoc Am Phys 1956; 69:56-63.

17. Smith K P and Bullen M. Bacteriuria in pregnancy. 1965: Lancet 1(7382): 395-99.

18. Little PJ: The incidence of urinary infection in 5000 pregnant women.Lancet 1966; 2(7470): 925-28.

19. Lee K.H, wong W.T Asymptomatic bacteriuria in Chinese pregnant women -- Bulletin of Hongkong Medical association 1970, 22: $81-85$.

20. Abdul Jabbar H, Moumena RA, Mosli HA, Khan AS, Warda.A Urinary tract infection in pregnancy —Ann Saudi med. 199;11(3): 322 - 4.

21. Olusanya O, Ogunledun, Fakoya T.A Asymptomatic significant bacteriuria among pregnant and nonpregnant insagamu, Nigeria-. West Afr.J Med; 12(1) :27 - 33.

22. Gebre-Selassie.S Asymptomatic bacteriuria in pregnancy-Clinical and microbiological approach -Ethiopian Med J. 1998;36(3):185-92.

23. Lavanya SV, Jogalakshmi D. Asymptomatic bacteriuria in antenatal women. Indian Journal of Medical Microbiology, 2002;20(2): 105-106.

24. Khattak AM, Khattak S, Khan H, Ashiq B, Mohammed D, Rafiq M. Prevalence of Asymptomatic bacteriuria in pregnant women Pak J Med Sci. 2006; 22(2): 162 - 166.

25. Turpin C, Minkah B. Danso KA, Frimpong EH. Asymptomatic bacteriuria in pregnant women attending antenatal clinic at the Komfo anokye teaching hospital, kumasi, Ghana. Ghana Med J. $2007 ; 41(1): 26-29$.
25. Abdullah AA, AL-Moslih MI. Prevalence of asymptomatic bacteriuria in pregnant women in sharjah, United Arab Emirates. East Mediterr Health J. 2005; 11(5-6) :1045- 52.

26. Birgul K, Ozene C, Altan A, Adyan B. Evaluation of Rapid urine screening test to detect Asymptomatic bacteriuria in pregnancy. JPn.J.Infect.Dis; 2006, 59(4), 261-263,206.

27. Hazir S. Asymptomatic bacteriuria in pregnancy. Urol J. 2007 ; 4(1) :24 - 7.

28. Imade $\mathrm{PH}$, Lzekor PE, Eghafona NO. Asymptomatic bacteriuria among pregnantwomen. North Am J Med Sciences June 2010;2(6):263-266.

30. Gayathree L, Shetty S, Deshpande S.R, Venkatesha DT. Screening forasymptomatic bacteriuria in pregnancy: An evaluation of various screening testsin Hassan District Hospital, India. 2010; 4(4): 2702-6.

31. Tugrul S, Oralo O, Kumro P, Kose D, Alka A, Yildirim G. Evaluation and importance of asymptomatic bateriuria in pregnancy. Clin Exo Obstet Gynecol. 2005;32:237-40

32. Wesley WE. Urinary tract infection, females. Med J 2002; 3: 33-41

33. Kiningham R. Asymptomatic bacteriuria in pregnancy. Am FamPhysician 1993; 47(5):12321238.

34. Maranchee JK, Capeleuto CC, Laughlin KR. Urinary tract infection during pregnancy. Infect Urol. 1997; 10: 152-57.

35. Celen S, Oruc AS, Karayalcin R, Saygan S, Vnlu $S$ Polat B. Asymptomatic bacteriuria and antibacterial susceptibility patterns in an obstetric population. ISRN Obstet Gynecol. 2011;721872:1-4

36. Fatima N, Ishrat S. Frequency and risk factors of asymptomatic bacteriuria during pregnancy. J Coll Physicians Surg Pak. 2006; 16:273-5. 